\title{
Protective Role of Elaesis guineensis Leaves against Crude Oil Tainted Diet- induced Hematotoxicity in Wistar Rats
}

\author{
Fidelis Ifeakachuku Achuba*id
}

Department of Biochemistry, Delta State University, Abraka, Nigeria.

\begin{tabular}{|c|c|}
\hline Article Info & A B S T R A C T \\
\hline $\begin{array}{l}\text { Article Type: } \\
\text { Research }\end{array}$ & \multirow{3}{*}{$\begin{array}{l}\text { Background: } \\
\text { Crude oil is a very toxic chemical. Recently, the search for protective substances is } \\
\text { attracting attention. This study aimed to investigate the hematoprotective } \\
\text { potentials of oil palm leaves against the toxicity induced by crude oil. }\end{array}$} \\
\hline Research & \\
\hline $\begin{array}{l}\text { Article History: } \\
\text { Received: 11.08.2019 }\end{array}$ & \\
\hline Accepted: 13.10 .2019 & \multirow{5}{*}{$\begin{array}{l}\text { Methods: } \\
\text { Male Wistar albino rats }(\mathrm{n}=36) \text { were divided into six groups of rats }(\mathrm{n}=6) \text {. Group } 1 \\
\text { (controls) were fed with normal rat food. Groups } 2 \text { and } 3 \text { were fed with diets } \\
\text { combined with a predetermined quantity of Elaesis guineensis (E. guineensis) } \\
\text { leaves. Group } 4 \text { were given crude oil contaminated diet. Groups } 5 \text { and } 6 \text { were fed } \\
\text { with tainted diet, mixed with a predetermined quantity of powdered E. guineensis } \\
\text { leaves. }\end{array}$} \\
\hline & \\
\hline $\begin{array}{l}\text { *Corresponding Author: } \\
\text { Fidelis Ifeakachuku Achuba }\end{array}$ & \\
\hline Department of Biochemistry, Delta & \\
\hline $\begin{array}{l}\text { State University, Abraka, Nigeria. } \\
\text { E-mail: achuba@delsu.edu.ng }\end{array}$ & \\
\hline
\end{tabular}

Results:

Pre-treatment of the diet with oil palm leaves restored lipid peroxidation, the activities of various types of superoxide dismutases (SODs), and catalase compared to those obtained for the control group. Treatment of crude oil-tainted diet with oil palm leaves significantly increased hemoglobin concentration and red blood cell indices, and significantly decreased white blood cell count compared to those noted for the rats fed crude oil-tainted diet.

Conclusions:

This study found that the treatment of crude oil contaminated diet with oil palm leaves reduced the hemotoxicity as experimented in Wistar albino rats.

Keywords:

Crude Oil; Elaesis Guineensis Leaves; Hemotoxicity; Oil-Tainted Rat Diet

How to cite this paper:

Achuba FI. Protective Role of Elaesis guineensis Leaves against Crude Oil Tainted Diet-induced Hematotoxicity in Wistar Rats. Iran J Toxicol. 2019;13(4): 1-4

\section{INTRODUCTION}

Free radicals are the most common reactive oxygen species in animals, the formation of which has been associated with crude oil (1). The generation of free radicals leads to the production of lipid peroxides, which inactivate antioxidant enzymes and induce oxidative stress (ㄹ). In fact, the disruption of antioxidant status in animals by crude oil has been established in the literature ( $\underline{3})$. Humans are exposed to crude oil during production, uses and illegal bunkering and refining $(\underline{4,5})$.

It is not surprising that most inhabitants of crude oil producing communities in the world are at risk of health issues that are linked to oxidative stresses $(\underline{6,7})$. Alterations in the levels of lipid peroxidation and the enzymatic and non-enzymatic antioxidants are reliable measures of assessing the oxidative stress in experimental animals $(\underline{8,9})$. The association of crude oil-induced oxidative stress with hemotoxicity conditions has been suggested in the literature (10). Products of the Elaesis guineensis (E. guineensis) tree are associated with medicinal properties due to their phytochemical and antioxidant effects (11-15). These attributes have been linked to E. guineensis leaves as a functional animal food ( $\underline{16})$. The aim of this study was to investigate the ability of $E$. guineensis leaves to protect against hemotoxicity induced in rats whose diet was contaminated with crude oil.

\section{MATERIALS AND METHODS}

Materials: Oil palm leaves was obtained from oil palm plantation in Obiaruku, Delta State, Nigeria. It was identified by Dr. Harrison Erhenhi, Department of Botany, Delta State University, Abraka, Nigeria. Crude oil was obtained from the Department of Petroleum Resources (DPR), Warri, Nigeria. All reagents used were of analytical grade. 
Male albino Wistar rats weighing 130-175g were obtained from a local animal dealer in Abraka and were identified by the Department of Anatomy, Delta state University, Abraka, Nigeria. The rats were kept in plastic cages and allowed to acclimatize for two weeks on grower's feed. The rats were handled based on the guidelines for the use of experimental animals throughout the study (17).

Methods: The preparation of oil palm leaves powder and treatment of diet followed an earlier protocol (18). The male Wistar albino rats $(n=36)$ were constituted into six groups of equal number of rats. Rats in group 1 (control) were fed with normal diet. Rats in groups 2 and 3 were fed with diets treated with a predetermined quantity of E. guineensis leaves. Rats in group 4 were fed with crude oil tainted diet $(4.0 \mathrm{~mL} / 100 \mathrm{~g})$. Rats in groups 5 and 6 were fed with the same tainted diet mixed with a predetermined amount of powdered $E$. guineensis leaves. All rats had access to water and food ad libitum throughout the four weeks of experiment. The feeds were prepared fresh daily and old feeds were discarded. At the end of the four weeks, the rats were sacrificed under chloroform anesthesia. Blood samples were collected in test tubes, and the lipid peroxidation activity assayed, using the protocol of Gutteridge and Wilkins (19). Total superoxide dismutase (SOD), copper/zinc superoxide dismutase (Cu/Zn SOD) and manganese superoxide dismutase (Mn SOD) activities were measured according to the protocols of Misra and Fredorich ( $\underline{20})$ and Crapo et al. (21). The protocol reported by Rani et al. (22) was applied to determine the catalase activity. The hematological parameters were determined with an automated hematology analyzer (Mindray analyzer, BC-2300, K.P. Diagnostic \& Instruments, India).
Statistical Analyses: All data were subjected to analysis of variance (ANOVA) and were expressed as means \pm standard deviations (SD) with the significant differences among the treatments set at 5\% confidence limit, i.e., $(\mathrm{P}<0.05)$.

\section{RESULTS}

As shown in Table 1, the lipid peroxidation significantly $(\mathrm{P}<0.05)$ increased in rats, fed with crude petroleum tainted diet compared to rats fed the normal diet. However, adding oil palm leaves to the diet returned the levels of lipid peroxidation to near the control levels. Crude oil tainted diet induced changes in the plasma total SOD, Cu/Zn SOD and Mn SOD (Table 1). However, pre-treatment of the rat food with oil palm leaves restored the activities of these enzymes to those noted for the control rats. Similarly, this trend was noted for the plasma catalase activity (Table 1), in which treatment of rat food with oil palm leaves maintained the catalase activity within the range noted for the control rats.

The hemoglobin level and red blood cell counts were significantly $(\mathrm{P}<0.05)$ decreased in rats, fed crude oil tainted diet compared to those noted for the control group. The white blood cell counts significantly $(\mathrm{P}<0.05)$ increased in rats fed the crude oil tainted food (Table 2). Treatment of crude oil-tainted diet with oil palm leaves significantly increased the hemoglobin concentration and red blood cell counts but significantly decreased the white blood cell counts (Table 2), compared to those noted for rats fed with crude oil-tainted diet.

Table 1. Effect of E. guineensis leaves treatment of diet on plasma oxidative stress markers in Wistar rats.

\begin{tabular}{cccccc}
\hline $\begin{array}{c}\text { GROUP } \\
\text { (N=6 each) }\end{array}$ & $\begin{array}{c}\text { Lipid peroxidation } \\
\text { (nmol/ml) }\end{array}$ & $\begin{array}{c}\text { Total SOD activity } \\
\text { (Unit/ml) }\end{array}$ & $\begin{array}{c}\text { Cu/Zn SOD activity } \\
\text { (Unit/ml) }\end{array}$ & $\begin{array}{c}\text { Mn SOD activity } \\
\text { (Unit/ml) }\end{array}$ & $\begin{array}{c}\text { Catalase activity } \\
\text { (Unit/ml) }\end{array}$ \\
\hline Group 1 & $0.733 \pm 0.160$ & $8.62 \pm 1.83$ & $6.36 \pm 0.13$ & $1.71 \pm 0.13$ & $4.80 \pm 0.81$ \\
Group 2 & $0.643 \pm 0.210$ & $8.03 \pm 0.43$ & $6.81 \pm 0.14$ & $1.65 \pm 0.43$ & $4.71 \pm 0.40$ \\
Group 3 & $0.622 \pm 0.083$ & $8.55 \pm 0.55$ & $6.74 \pm 0.16$ & $2.55 \pm 0.31$ & $4.66 \pm 0.22$ \\
Group 4 & $1.15 \pm 0.110$ & $6.21 \pm 1.02$ & $4.88 \pm 0.30$ & $2.1 \pm 0.08$ & $3.81 \pm 0.56$ \\
Group 5 & $0.625 \pm 1.13$ & $7.43 \pm 1.00$ & $6.05 \pm 0.24$ & $1.77 \pm 0.23$ & $4.22 \pm 0.26$ \\
Group 6 & $0.632 \pm 1.10$ & $7.21 \pm 1.13$ & $6.22 \pm 0.31$ & $1.61 \pm 0.48$ & $4.16 \pm 0.32$ \\
\hline
\end{tabular}

The results are expressed as mean \pm standard deviation with $n=6$. Values not sharing a common superscript on the same vertical column differ significantly. $\mathrm{SOD}=$ superoxide dismutase; $\mathrm{Cu} / \mathrm{Zn} \mathrm{SOD}=$ copper/zinc superoxide dismutase; $\mathrm{Mn} \mathrm{SOD}=$ Manganese superoxide dismutase.

Table 2. Effect of E. guineensis leaves treatment of diet on hematological markers in Wistar rats.

\begin{tabular}{ccccccc}
\hline $\begin{array}{c}\text { Group } \\
\text { (N=6 each) }\end{array}$ & Hb (mg/dl) & PCV (\%) & RBC (x1012/L) & WBC $\left(x 10^{9} / \mathrm{L}\right)$ & MCV & MCH \\
\hline Group 1 & $15.21 \pm 1.67^{\mathrm{a}}$ & $40.13 \pm 0.63^{\mathrm{a}}$ & $10.48 \pm 4.31^{\mathrm{a}}$ & $17.07 \pm 5.77^{\mathrm{a}}$ & $4.52 \pm 2.33^{\mathrm{a}}$ & $0.38 \pm 0.05^{\mathrm{a}}$ \\
Group 2 & $17.34 \pm 2.40^{\mathrm{b}}$ & $43.88 \pm 1.65^{\mathrm{b}}$ & $13.71 \pm 2.62^{\mathrm{b}}$ & $18.22 \pm 2.39^{\mathrm{a}}$ & $3.28 \pm 0.56^{\mathrm{a}}$ & $0.40 \pm 0.35^{\mathrm{a}}$ \\
Group 3 & $19.61 \pm 0.89^{\mathrm{c}}$ & $46.13 \pm 1.65^{\mathrm{c}}$ & $16.41 \pm 1.67^{\mathrm{c}}$ & $17.34 \pm 0.88^{\mathrm{a}}$ & $2.84 \pm 0.23^{\mathrm{a}}$ & $0.43 \pm 0.02^{\mathrm{a}}$ \\
Group 4 & $8.50 \pm 2.40^{\mathrm{d}}$ & $21.13 \pm 4.19^{\mathrm{d}}$ & $5.39 \pm 1.61^{\mathrm{d}}$ & $25.49 \pm 3.90^{\mathrm{b}}$ & $4.40 \pm 2.16^{\mathrm{a}}$ & $0.44 \pm 0.21^{\mathrm{a}}$ \\
Group 5 & $10.26 \pm 3.98^{\mathrm{e}}$ & $30.50 \pm 4.20^{\mathrm{d}}$ & $6.35 \pm 1.76^{\mathrm{e}}$ & $19.61 \pm 1.70^{\mathrm{a}}$ & $5.26 \pm 2.24^{\mathrm{a}}$ & $0.40 \pm 0.20^{\mathrm{a}}$ \\
Group 6 & $13.49 \pm 1.22^{\mathrm{a}}$ & $37.88 \pm 6.56^{\mathrm{e}}$ & $9.50 \pm 0.91^{\mathrm{ab}}$ & $19.47 \pm 1.06^{\mathrm{a}}$ & $4.07 \pm 1.11^{\mathrm{a}}$ & $0.40 \pm 0.19^{\mathrm{a}}$ \\
\hline
\end{tabular}

The results are expressed as mean \pm standard deviation with $n=6$. Superscripts values not sharing a common superscript on the same vertical column differ significantly. $\mathrm{Hb}=$ haemoglobin concentration; $\mathrm{PCV}=$ Packed cell volume; $\mathrm{RBC}=\mathrm{Red}$ blood cell count; $\mathrm{WBC}=\mathrm{White}$ blood cell count; $\mathrm{MCV}=$ Mean corpuscular volume; $\mathrm{MCH}=$ Mean corpuscular hemoglobin.

\section{DISCUSSION}

Blood is an important means of transporting and supplying nutrients and oxygen to bodily tissues and organs in all animals and humans. More importantly, blood is in charge of the regulation of animal's internal homeostasis and represents the first source for toxicological assessments $(\underline{23})$. The induction of plasma 
lipid peroxidation, the concomitant reduction in antioxidant enzymes by petroleum, and the treatment by antioxidant rich substances have been published elsewhere (24). The results of this study indicated that crude oil tainted diet altered plasma oxidative stress indicators. However, the addition of oil palm leaves in rat diet restored the indices to levels approaching those noted for the control group. Also, the protective properties of oil palm leaves has previously been documented ( $\underline{25})$. The increase in the oxidative stress status of the plasma during crude oil abuses and the resultant anemia have previously been reported by other studies $(\underline{26,27})$. The same could be mentioned of induction of disease processes by crude oil (28). This is the basis for the alteration of hematological indices in animals exposed to crude oil (29). It is on this premise that it is imperative to monitor the protective effects of oil palm leaves against hemotoxicity following the exposure of animal to foods contaminated with crude oil.

As seen in Table 2, the significant decrease in hematological indices in rats fed with crude oil contaminated diet as compared to that for the controls, supports the findings of previous studies on the hemotoxic effects of crude oil contaminations (30-32). The decreased hemoglobin concentration and related hematological indices have been attributed to decreased hematopoiesis and enhanced hemolysis induced by hydrocarbons ( $\underline{33})$. The treatment of crude oil-contaminated diet with oil palm leaves significantly returned the hemoglobin concentration and red blood cell counts to values close to those noted in the control rats.

Unlike hemoglobin and red blood cell indices, we observed a significant increase $(\mathrm{P}<0.05)$ in the white blood cell (WBC) counts in rats fed with crude oilcontaminated food compared to those seen in the controls ( Table 1). This observation was in agreement with the previous findings, suggesting that increases in WBC represent induction of a disease process (34). Moreover, oil palm leaves treatment of rat diet significantly decreased the WBC compared to the levels noted in rats fed with crude oil-tainted diet only. These observations, i.e., the positive alterations in hematological indices, suggest that oil palm leaves can protect against crude oil-induced hemotoxicity. The protective potential of the leaves against the toxicity was linked to the presence of polyphenolic compounds with the attendant antioxidant effects, which had been previously reported by another study ( $\underline{35})$.

\section{CONCLUSIONS}

This study discovered that the treatment of crude oiltainted diet with oil palm leaves reduced the resultant and expected hemotoxicity in Wistar albino rats.

\section{ACKNOWLEDGEMENTS}

The author acknowledges the support of Dr. Joel Okpoghono and Mr. Murphy D. Ogwumu for providing the technical assistance in the analyses of hematological and oxidative stress indicators, respectively.

\section{CONFLICT OF INTERESTS}

The author has no conflict of interest to declare.

\section{REFERENCES}

1. Achuba FI, Osakwe SA petroleum induced free radical toxicity in African catfish (Clarias gariepinus). Fish Physiol Biochem. 2003;29:97-103.

2. Anozie OI, Onwurah IN. Toxic effects of Bonny light crude oil on rats after ingestion of contaminated diet. Nig J Biochem Mol Biol. 2001;16:103S-108S.

3. Adedara IA, Teberen R, Ebokaiwe AP, et al. Induction of oxidative stress in liver and kidney of rats exposed to Nigerian Bonny light crude oil. Environ Toxicol. 2012;27:372-379.

4. Otitoju 0, Onwurah INE. Preliminary investigation into the possible endocrine disrupting activity of Bonny light crude oil contaminated diet in Wistar rats. Biokemistri. 2007;19(2):23-28.

5. Ogudu Ad, Esemuede IH. Crude oil theft and its environmental consequences: The way forward. J Nig Environ Society. 2013;7(4):1-18.

6. Achuba FI. Effect of vitamins $\mathrm{C}$ and $\mathrm{E}$ on blood Lipid concentrations, lipid peroxidation, superoxide dismutase and catalase activities in rabbit fed petroleum contaminated diet. Pakistan J Nutr. 2005;4(5):330-335.

7. Odinioha B, Brisibe S. The human health implications of crude oil spills in the Niger delta, Nigeria. An interpretation of published studies: Nigerian Medical Journal. 2013;54(1):10-16.

8. Achuba FI. Petroleum products in soil mediated oxidative stress in cowpea (Vigna unguiculata) and maize (Zea mays) seedlings. Open J Soil Sci. 2014;4:417-435.

9. Achuba FI. Modulation of crude oil induced alteration of oxidative stress indices in rats by red palm oil. J Appl SCi Environ Mgt. 2018a;22(6):929-932.

10. Achuba FI. Evaluation of the protective effects of bitter Leaves (Vernonia amygdalina) on hematological indices of rats fed with crude oil treated diet. J. Appl. Sci. Environ. Mgt. 2018b;22(4):489-492.

11. Runnie I, Nordin MM, Radzali M, et al. Antioxidant and hypocholesteromic effects of Elaeis guineensis leaves extract on hypercholesteromic rabbits. ASEAN Food J. 2003;12:137-147.

12. Chong KH, Zuraini Z, Sasidharan S, et al. Antimicrobial activity of Elaeis guineensis leaf. Pharmacology Online. 2008;3:379-386.

13. Rout SP, Choudary KA, Kar DM, et al. Plants in traditional medicinal system - future source of new drugs. Intl J Pharm Pharm Sci. 2009;5(4):137-140.

14. Sasidharan S, Logeswaran S, Latha LY. Wound healing activity of Elaeis guineesis leaves extract ointment. Intl J Mol Sci. 2012;13:336-347.

15. Yin NS, Abdullah S, Phin, KC. Phytochemical constituents from leaves of Elaeis guineesis and their antioxidant and antimicrobial activities. Intl. J Pharm. Pharm Sci. 2013;5(4):137-140. 
16. Mohamed SK. Elaesis guineensis Leaf: A new functional food ingredient for health and disease prevention. J. Food Process Technol. 2014;5(2):300-306.

17. NRC (National Research Council). Guide for the care and use of laboratory animals (8th ed). Institute of Laboratory Animal Resources, National Academy Press, 2011.

18. Achuba FI Powdered oil palm (Elaesis guineensis Jacq) leaf as remedy for hydrocarbon induced liver damage in rats. Nig J Pharm Appl Sci Res. 2018c;7(3):89-95.

19. Guttridge JMC, Wilkins C. Copper dependent hydroxyl radical damage to ascorbic acid formation of thiobarbituric acid reactive products. FEBS Letters. 1982;137:327-340.

20. Misra HP, Fridovich I. The role of superoxide anion in the auto-oxidation of epinephrine and a sample assay for superoxide dismutase. J. Biol. Chem. 1972;247:31703175.

21. Crapo JD, McCord JM, Fridovich I. Preparation and assay of superoxide dismutases. Meth. Enzymol. 1978;(53):382-393.

22. Rani P, Meena UK, Karthikeyan J. Evaluation of antioxidant properties of berries. Indian J Clin Biochem. 2004;19(2):103-110.

23. Achuba FI, Ubogu LA, Ekute BO. Moringa oleifera treatment prevents crude oil tainted diet imposed toxicity in rats. Sokoto J Med Lab Sci. 2018;3(3):99-105.

24. Okpoghono J, George BO, Achuba FI. Assessment of antioxidant indices after incorporating crude oil Contaminated catfish and African Nutmeg (Monodora myrstica) extracts into rat diet. J. Appl. Sci. Environ. Mgt. 2018;22(2):197-202.

25. Achuba FI. Protective influence of Elaesis guineensis leaf in diet on petroleum-mediated kidney damage in rats. Nig J Pharm Appl Sci Res. 2018d;7(2):33-38.
26. Achuba FI, Peretiemo-Clarke BO, Okolie TC. Oxidative stress in the brain of rabbits with petroleum-induced hypoglycaemia. Biol Lett. 2005;42(1):33-39.

27. Achuba FI, Awhin PE. Protective influence of antioxidant vitamins on hematological indices of rabbits fed crudeoil-contaminated diet. Toxic Environ Chem. 2009;91(3):505-510.

28. Achuba FI, Obaremi C. Effects of selenium fortified diet on inflammatory markers in Wistar albino rats exposed to crude oil. Nig J Pharm Biomed Res. 2018;3(3):209-216.

29. Achuba FI. Evaluation of the protective effects of Bitter Leaf (Vernonia amygdalina) on hematological indices of rats fed with crude oil treated diet. J. Appl. Sci. Environ. Management. 2018e;22(4):489-492.

30. Achuba FI, Ogwumu MD. Effect of palm oil and beef liver on diesel-induced hemotoxicity in Wistar albino rats. Biokemistri. 2014;26(4):120-123.

31. Achuba FI, Nwokogba CC. Effect of honey supplementation on hematological parameters of Wistar albino rats fed hydrocarbon contaminated diets. Biokemistri. 2015;27(1):44-49.

32. Emelike OF, Okhuakhua OJ, Momodu MM, et al. Some hematological parameters of petrol attendants and automobile mechanics in Ekpoma, Edo State, Nigeria. Sch J Appl Med Sci. 2015;3(3E):1400-1403.

33. Ita SO, Udofia AU. Comparative study of some hematological parameters in rat following ingestion of crude oil (Nigeria Bonny Light), petrol, kerosene and diesel. Asian J Biol Sci. 2011;4:498-505.

34. Achuba FI. Effect of Moringa oleifera on crude oil mediated hemotoxicity in Wistar albino rats. Nig. J. Pure \& Appl. Sci. 2018f;31(2):3192-3196.

35. Soundararajan V, Sreenivasan S. Antioxidant activity of Elaeis guineensis leaf extract: An alternative nutraceutical approach in impeding aging. APCBEE Procedia. 2012;2:153-159. 